Folia Cardiologica 2019 tom 14, nr 1, strony 46-51 DOI: 10.5603/FC.2019.0009 Copyright (C) 2019 Via Medica ISSN 2353-7752

\title{
Interakcje wybranych leków kardiologicznych ze składnikami diety
}

\section{Cardiovascular drug interactions with dietary components}

\author{
Iwona Zieleń-Zynek ${ }^{1}$, Joanna Kowalska ${ }^{1}$, Agnieszka Będkowska-Szczepańska ${ }^{2}$, \\ Grzegorz Ziółkowski ${ }^{3}$, Mariusz Gąsior ${ }^{4}$, Bartosz Hudzik ${ }^{3,4}$, Barbara Zubelewicz-Szkodzińska ${ }^{1,2}$ \\ ${ }^{1}$ Zakład Profilaktyki Chorób Żywieniowozależnych Katedry Profilaktyki Chorób Metabolicznych \\ Wydziału Zdrowia Publicznego w Bytomiu, Śląski Uniwersytet Medyczny w Katowicach \\ ${ }^{2}$ Odział Endokrynologii Piekarskiego Centrum Medycznego w Piekarach Śląskich \\ ${ }^{3}$ Zakład Profilaktyki Chorób Sercowo-Naczyniowych Katedry Profilaktyki Chorób Metabolicznych \\ Wydziału Zdrowia Publicznego w Bytomiu, Śląski Uniwersytet Medyczny w Katowicach \\ ${ }^{4}$ III Katedra i Oddział Kliniczny Kardiologii Śląskiego Centrum Chorób Serca w Zabrzu, Wydział Lekarski \\ z Oddziałem Lekarsko-Dentystycznym w Zabrzu, Śląski Uniwersytet Medyczny w Katowicach
}

\section{Streszczenie}

Starzejące się społeczeństwo i narastający problem wielochorobowości przyczyniają się do powstania potrzeby długotrwałego stosowania leków kardiologicznych, a co za tym idzie - zwiększa się ryzyko wystąpienia interakcji. Celem niniejszej pracy jest przedstawienie interakcji leków stosowanych w praktyce klinicznej kardiologa z żywnością. Działanie antagonistów witaminy K nasilają m.in.: szałwia, rumianek, natka pietruszki, anyż, lukrecja, imbir, żeń-szeń, sok żurawinowy i sok grejpfrutowy. $Z$ kolei produkty bogate $w$ witaminę $\mathrm{K}$ hamują efekt terapeutyczny pochodnych kumaryny. Ze względu na zwiększone ryzyko krwawień leków przeciwpłytkowych nie należy łączyć z suplementami diety zawierającymi miłorząb japoński (Ginkgo biloba), który hamuje czynnik aktywujący płytki. W piśmiennictwie wskazuje się na wystąpienie podobnego ryzyka przy stosowaniu leków przeciwpłytkowych wraz z suplementami zawierającymi czosnek. Osoby regularnie przyjmujące leki kardiologiczne narażone są na występowanie interakcji między żywnością a lekami. Najbardziej znana i najlepiej poznana jest interakcja grejpfruta lub soku z tego owocu z lekami doustnymi metabolizowanymi w wątrobie za pośrednictwem cytochromu P450 3A4 (CYP3A4). Zwraca się uwagę na możliwy wzrost stężenia przyjmowanych leków (przy prawidłowym ich dawkowaniu), które wiąże się ze zwiększonym prawdopodobieństwem wystąpienia działań niepożądanych. W licznych badaniach naukowych sprawdza się wpływ żywności na wchłanianie leków hipotensyjnych. Istnieje pilna potrzeba edukacji pacjentów w obszarze interakcji leków z żywnością. W tym celu należy utworzyć zespół terapeutyczny, składający się z: lekarza prowadzącego, lekarza specjalisty - kardiologa, psychologa, pielęgniarki oraz dietetyka.

Słowa kluczowe: interakcja, leki sercowo-naczyniowe, składniki diety

Folia Cardiologica 2019; 14, 1: 46-51

Adres do korespondencji: dr n. med. Bartosz Hudzik, III Katedra i Oddział Kliniczny Kardiologii, Śląskie Centrum Chorób Serca w Zabrzu, Wydział Lekarski z Oddziałem Lekarsko-Dentystycznym w Zabrzu, Śląski Uniwersytet Medyczny w Katowicach, ul. Curie-Skłodowskiej 9, 41-800 Zabrze, e-mail: bartekh@mp.pl

*Równorzędne pierwsze autorstwo 


\section{Wstęp}

Ze względu na wzrastające obecnie stosowanie leków w krajach europejskich zagadnienie oddziaływania między sobą poszczególnych leków, a także interakcji leków z żywnością staje się coraz bardziej istotne dla lekarzy, farmaceutów, naukowców, a także dla pacjentów. Według danych Głównego Urzędu Statystycznego (GUS) z 2014 roku, zebranych na podstawie Europejskiego Ankietowego Badania Zdrowia (EHIS, European Health Interview Survey), 77\% kobiet oraz 63\% mężczyzn w Polsce zażywa leki ze wskazań lekarza oraz bez recepty. W grupie nastolatków leki przyjmuje $50 \%$ osób, z kolei wśród 50-latków odsetek ten wzrasta do niemal $80 \%$. Do leków najczęściej przepisywanych przez lekarzy w Polsce zalicza się: leki obniżające ciśnienie krwi, analgetyki oraz leki obniżające stężenie cholesterolu. Według raportu najczęściej kupowane przez Polaków preparaty bez recepty to witaminy i składniki mineralne, następnie leki przeciwbólowe oraz leki na przeziębienie i grypę [1].

Do wzmożonego zainteresowania mnogością interakcji z żywnością przyczyniają się również takie czynniki, jak starzejące się społeczeństwo i implikacje kliniczne podeszłego wieku. Jedną z typowych cech pacjenta geriatrycznego jest wielochorobowość, a co za tym idzie - zwiększenie liczby przyjmowanych leków [2].

Interakcję definiuje się jako „wzajemne oddziaływanie na siebie dwóch lub więcej substancji, w którego wyniku ulegają zmianie ich indywidualne właściwości lub łączny skutek". Interakcje między lekiem a żywnością mogą zachodzić na każdym etapie farmakokinetyki leku w organizmie: uwalniania, wchłaniania, dystrybucji, metabolizmu oraz wydalania [3]. Celem niniejszej pracy jest przedstawienie interakcji leków stosowanych w praktyce klinicznej kardiologa z żywnością.

\section{Leki przeciwkrzepliwe a składniki diety}

Starzejące się społeczeństwo i narastający problem wielochorobowości przyczyniają się do powstania potrzeby długotrwałego stosowania leków kardiologicznych, w tym środków przeciwkrzepliwych. Jest to grupa leków, która wykazuje silne interakcje zarówno z innymi lekami, jak i z żywnością, a powikłania przez nie spowodowane są jedną z najczęstszych przyczyn hospitalizacji [4].

Antagoniści witaminy $\mathrm{K}$ (VKA, vitamin $\mathrm{K}$ antagonists) - acenokumarol oraz warfaryna - to najczęściej przepisywane leki przeciwzakrzepowe na świecie [5]. Po podaniu doustnym acenokumarol jest szybko wchłaniany, metabolizowany w wątrobie i wydalany głównie z moczem (60\%) oraz kałem (29\%) [6]. Pacjenci zażywający doustne antykoagulanty zazwyczaj jednak nie wiedzą, jakie pokarmy wchodzą z nimi w interakcje, lub lekceważą tę wiedzę, nie zdając sobie sprawy, jak szkodliwe efekty mogą one wywołać podczas leczenia. Niebezpieczne są zarówno pokarmy nasilające, jak i osłabiające działanie VKA.
Najlepiej znane lekarzom oraz pacjentom interakcje doustnych antykoagulantów, pochodnych kumaryny, to interakcje z produktami bogatymi w witaminę K [6]. Dieta bogata w produkty zawierające powyżej $100 \mu$ g witaminy K w 100 g produktu (szpinak, jarmuż, zielona sałata, brukselka, herbata zielona) oraz produkty zawierające 50-100 $\mu$ g witaminy $\mathrm{K}$ w 100 g produktu (m.in. kapusta, kalafior, awokado, pistacje) hamują działanie warfaryny oraz acenokumarolu [7]. W badaniu z udziałem 66 pacjentów przyjmujących warfarynę wykazano zależność między zawartością witaminy $\mathrm{K}$ w diecie a krzepliwością krwi. Osoby badane podzielono na 3 grupy w zależności od ilości spożywanej witaminy K: o niskiej, średniej oraz wysokiej podaży witaminy K. W badaniu wykazano, że międzynarodowy wskaźnik znormalizowany (INR, international normalized ratio) koreluje ujemnie z zawartością witaminy $\mathrm{K}$ w diecie pacjentów. Ponadto INR był istotnie niższy w grupie pacjentów z najwyższą podażą witaminy K w stosunku do grupy pacjentów o najniższej podaży witaminy $\mathrm{K}$ [8].

Z kolei Saito i wsp. [9] wnioskują, że hamujący wpływ witaminy K dostarczonej z żywnością na efekt terapeutyczny warfaryny częściowo zależy od genotypu. W badaniu z udziałem 202 pacjentów kliniki kardiologicznej w Japonii oceniono wpływ leczenia warfaryną ze względu na polimorfizm genów VKORC1 oraz CYP2C9, uwzględniając podaż witaminy $\mathrm{K}$ $z$ dietą. Ze względu na zawartość witaminy $\mathrm{K}$ w tygodniowej diecie pacjenci zostali podzieleni na trzy grupy spożycia: niskiego $(<18 \mu \mathrm{g})$, średniego $(18-36 \mu \mathrm{g})$ oraz wysokiego ( $\geq 36 \mu \mathrm{g})$. Wykazano, że heterozygoty VKORC1-1639 A/G wymagały istotnie wyższej dawki warfaryny niż homozygoty VKORC1-1639 A/A ( $<$ 0,0001). Nie stwierdzono podobnej zależności u pacjentów z genotypem CYP2C9. Z kolei heterozygoty VKORC1-1639 A/G z grupy niskiego spożycia witaminy $\mathrm{K}$ potrzebowały istotnie niższej dawki warfaryny w porównaniu z grupami średniego i wysokiego spożycia witaminy $\mathrm{K}(\mathrm{p}<0,05)[9]$.

Łączenie VKA z sokiem żurawinowym lub grejpfrutowym powoduje zwiększenie wartości INR na drodze hamowania enzymu odpowiedzialnego za metabolizm antagonistów witaminy $\mathrm{K}$, zwiększa się tym samym ryzyko wystąpienia powikłań krwotocznych [4]. Działanie antagonistów witaminy K nasilają również: szałwia, rumianek, natka pietruszki, anyż, lukrecja, imbir, żeń-szeń i inne [4, 6]. Liczne interakcje VKA z innymi lekami oraz z żywnością były powodem rozpoczęcia badań nad alternatywnym sposobem leczenia. W 2009 roku wprowadzono doustne leki przeciwkrzepliwe niebędące antagonistami witaminy K (NOAC, non-vitamin K antagonists oral anticoagulants) [10].

\section{Leki przeciwpłytkowe a składniki diety}

Do grupy leków przeciwpłytkowych zalicza się kwas acetyIosalicylowy (ASA, acetylosalicylic acid), a także inhibitory receptora $\mathrm{P}_{2} \mathrm{Y}_{12}$ (klopidogrel, prasugrel, tikagrelor). Kwas acetylosalicylowy należy do grupy niesteroidowych leków 
przeciwzapalnych (NLPZ), jednak w latach 70. XX wieku zaczęto go stosować również jako lek przeciwpłytkowy. Podstawą mechanizmu działania ASA jest hamowanie cyklooksygenazy (COX, cyclooxygenase) [11]. Z kolei działanie antyagregacyjne inhibitorów receptora $P 2 Y_{12}$ polega na blokowaniu adenozynodifosforanowo-zależnego (ADP, adenosine diphosphate) szlaku aktywacji płytek krwi.

Kwasu acetylosalicylowego nie należy łączyć z alkoholem ze względu na działanie hamujące aktywność dehydrogenazy alkoholowej. W efekcie zwiększa się czas metabolizmu alkoholu do aldehydu octowego [12]. Z kolei miłorząb japoński, podobnie jak czosnek i cebula (składniki suplementów diety dostępnych bez recepty), istotnie nasilają działanie doustnych leków przeciwzakrzepowych przez zmniejszanie agregacji płytek [13].

Wzrost popularności suplementów diety w ostatnich latach, jak również stosowanie ich bez konsultacji z lekarzem zwiększa u pacjentów ryzyko wystąpienia interakcji z zażywanymi lekami. Ze względu na zwiększone ryzyko krwawień leków przeciwpłytkowych nie należy łączyć z suplementami diety zawierającymi miłorząb japoński (Ginkgo biloba), który hamuje czynnik aktywujący płytki (PAF, platelet activating factor). W piśmiennictwie wskazuje się na wystąpienie podobnego ryzyka przy stosowaniu leków przeciwpłytkowych wraz z suplementami zawierającymi czosnek. Zawarta w nim allicyna hamuje agregacje płytek krwi [14].

Żeń-szeń wykazuje działanie przeciwzakrzepowe w wyniku hamowania kilku etapów szlaku agregacji płytek krwi - potwierdzono to w badaniach klinicznych. Z tego względu warto zwrócić uwagę na stosowanie przez pacjentów suplementów zawierających żeń-szeń przy jednoczesnym stosowaniu leków przeciwpłytkowych, jednak według badań klinicznych ryzyko to jest niewielkie [15].

Paraoksonaza 1 (PON1) to enzym wpływający na odpowiedź kliniczną na klopidogrel, z kolei dieta bogata w kwas askorbinowy (witamina C) oraz tokoferol (witamina E) nasila wytwarzanie PON1 [16].

\section{Leki hipotensyjne a składniki diety}

Nadciśnienie tętnicze stanowi zasadniczy modyfikowalny czynnik ryzyka chorób układu sercowo-naczyniowego (CVD, cardiovascular disease) [17]. W badaniu NATPOL wykazano, że obecnie na nadciśnienie tętnicze w Polsce choruje 47\% mężczyzn i 56\% kobiet. Leki hipotensyjne stosuje 23\% Polaków w wieku od 15 lat [18]. Wśród środków leczniczych obniżających ciśnienie tętnicze zastosowanie terapeutyczne znajdują: inhibitory konwertazy angiotensyny (ACE, angiotensin-converting enzyme), antagoniści receptora angiotensynowego (ARB, angiotensin receptor blockers), beta-adrenolityki, antagoniści wapnia oraz diuretyki [19].

W licznych badaniach naukowych sprawdza się wpływ żywności na wchłanianie leków hipotensyjnych. Istotne klinicznie interakcje żywność-lek są indukowane przez zmiany w biodostępności leku wywoływane przez pożywanie [19]. Ramalingam i wsp. [20] w badaniu z 2018 roku z udziałem 685 pacjentów kardiologicznych, trwającym 12 miesięcy, stwierdzili, że interakcje zachodzące między lekami obniżającymi ciśnienie a pokarmem mogą stanowić istotne zagrożenie dla zdrowia oraz obniżać skuteczność działania leków hipotensyjnych. Wykazano możliwość wystąpienia interakcji farmakokinetycznych między atenololem a sokiem pomarańczowym u 79 badanych pacjentów $[20,21]$. Obserwowano ryzyko wystąpienia hiperkaliemii u 47 badanych pacjentów przyjmujących enalapril bezpośrednio przed zjedzeniem banana lub po jego spożyciu [20].

Stosowanie korzenia lukrecji w codziennej diecie osób chorujących na nadciśnienie tętnicze może skutkować retencją sodu i wody w organizmie tych chorych oraz utratą potasu, a w efekcie - obrzękami oraz wzrostem ciśnienia tętniczego [22, 23]. Potrawy zawierające ekstrakt z korzenia lukrecji (chleb z lukrecją i orzechami, gnocchi z lukrecjową posypką, sernik z lukrecją, ciastka z lukrecją, cukierki lukrecjowe, nalewka z korzenia lukrecji, napoje na bazie lukrecji i in.) wykazują właściwości hipertensynogenne, co w konsekwencji może zmniejszać skuteczność leków hipotensyjnych [24]. Według Woźnickiej-Leśkiewicz i wsp. [19] przyjmowanie diuretyków wymaga spożywania żywności bogatej w potas (pomarańczy, bananów, ziemniaków, pomidorów) i równocześnie unikania lukrecji, nasilającej działanie hipokaliemiczne.

Jedną z najbardziej znanych i równocześnie najlepiej poznanych działań jest interakcja z grejpfrutem (całym owocem świeżym, mrożonym czy sokiem) oraz innymi owocami zawierającymi furanokumaryny (pomarańcze z Sevilli, pomelo, limonki). Bioaktywne składniki diety zawarte w tych owocach wpływają na wchłanianie określonych leków przez między innymi wpływ na ich metabolizm w wątrobie. Leki wchodzące w interakcje z tymi owocami są podawane doustnie, ich biodostępność jest niska (<10\%) lub umiarkowana ( > 30-70\%) i są metabolizowane z użyciem cytochromu P453A4 (CYP3A4). Furanokumaryny zawarte w owocach/ sokach ulegają metabolizmowi z udziałem opisanego układu enzymatycznego do reaktywnych półproduktów, które przyłączają się kowalencyjnie do miejsca aktywnego w enzymie, powodując nieodwracalną inaktywację enzymu. W następstwie aktywność CYP3A4 w jelicie cienkim pozostaje upośledzona aż do uzupełnienia jego stężenia przez syntezę enzymu de novo i przywrócenie jego początkowego stężenia. Cały owoc lub $200 \mathrm{ml}$ soku to wystarczająca ilość do wywołania interakcji lekowej, może spowodować klinicznie istotny wzrost stężenia leku przekraczający stężenie terapeutyczne i w następstwie - odpowiednie działania niepożądane (tab. 1). Inne owoce cytrusowe (słodkie pomarańcze, pomarańcze bezpestkowe), niezawierające furanokumaryn, nie powodują takich interakcji [25-28].

Według autorów, przeciwwskazaniem do spożywania grejpfruta oraz soku grejpfrutowego jest terapia nadciśnienia tętniczego lekami z grupy beta-adrenolityków oraz 
Tabela 1. Interakcje między lekami kardiologicznymi i grejpfrutem oraz potencjalne działania niepożądane

\begin{tabular}{|c|c|c|}
\hline Grupa leków & Przewidywane ryzyko interakcji grejpfrut-lek & Działanie niepożądane wynikające z interakcji \\
\hline \multicolumn{3}{|l|}{ Leki antyarytmiczne } \\
\hline Amiodaron & Duże & Torsade de pointes \\
\hline Dronedaron & Bardzo duże & Torsade de pointes \\
\hline Chinidyna & Umiarkowane & Torsade de pointes \\
\hline Propafenon & Umiarkowane & $\begin{array}{l}\text { Bradykardia, zaburzenia przewodzenia przed- } \\
\text { sionkowo-komorowego }\end{array}$ \\
\hline Werapamil & Duże & Blok przedsionkowo-komorowy (całkowity) \\
\hline \multicolumn{3}{|l|}{ Leki hipotensyjne } \\
\hline $\begin{array}{l}\text { Felodipina, nikardipina, nifedipi- } \\
\text { na, nimodipina, nitrendipina }\end{array}$ & Umiarkowane & Niedociśnienie, obrzęki obwodowe \\
\hline Amlodipina & Małe & Niedociśnienie, obrzęki obwodowe \\
\hline Losartan & Umiarkowane & Utrata działania hipotensyjnego \\
\hline \multicolumn{3}{|l|}{ Leki hipolipemizujące } \\
\hline Atorwastatyna & Duże & Rabdomioliza \\
\hline Lowastatyna, simwastatyna & Bardzo duże & Rabdomioliza \\
\hline \multicolumn{3}{|l|}{ Leki przeciwkrzepliwe } \\
\hline Apiksaban & Duże & Krwawienia \\
\hline Riwaroksaban & Umiarkowane & Krwawienia \\
\hline \multicolumn{3}{|l|}{ Leki przeciwpłytkowe } \\
\hline Klopidogrel & Duże & Utrata działania przeciwpłytkowego \\
\hline Tikagrelor & Duże & Krwawienia \\
\hline \multicolumn{3}{|l|}{ Inne } \\
\hline Eplerenon & Duże & Hiperkaliemia, zaburzenia rytmu serca \\
\hline Sildenafil & Umiarkowane & Niedociśnienie \\
\hline Kolchicyna & Umiarkowane & Neutropenia, neuropatia \\
\hline
\end{tabular}

antagonistów kanału wapniowego [19, 29, 30]. Pojedyncza porcja soku grejpfrutowego (200-250 ml) lub cały grejpfrut mają wystarczający potencjał, aby spowodować odpowiednie interakcje, na przykład stężenie felodypiny popitej wymienioną objętością soku wzrasta 3-krotnie bardziej niż popitej wodą. W przypadku powtarzanego spożywania soku (np. $250 \mathrm{ml} 3$ × d. przez 6 kolejnych dni) stężenie leku wzrasta 5-krotnie w porównaniu z lekiem popitym wodą, co wskazuje, że również częstość spożycia przeciętnej ilości soku wpływa na farmakokinetykę leku. Co więcej, również czas od spożycia soku do przyjęcia leku ma znaczenie - najwyższy wzrost stężenia leku obserwuje się po 4 godzinach od spożycia soku [27, 28], z kolei wydłużenie czasu spożycia leku od spożycia soku powoli zmniejsza interakcję (odstęp 10-godz. zmniejsza o 50\%, a odstęp 2-dniowy - o 75\%) [26]. Do najczęstszych objawów interakcji grejpfrut-leki należą: zaburzenia rytmu serca, rabdomioliza, neurotoksyczność i rak piersi. Rabdomiolizę obserwuje się głównie w trakcie leczenia z zastosowaniem inhibitorów 3-hydroksy-3-metyloglutarylokoenzymu A (HMG-CoA, hydroxy-methylg/utaryl coenzyme A) - statyn.
Obserwacje takie opisano w przypadku simwastatyny, lowastatyny i atorwastatyny. Warto jednak dodać, że brakuje takich obserwacji w przypadku prawastatyny, fluwastatyny i rosuwastatyny. Neurotoksyczność stwierdzono w przypadku stosowania leków hamujących odrzucenie przeszczepu (cyklosporyna, takrolimus). Biodostępność cyklosporyny po popiciu leku sokiem grejpfrutowym jest o 162\% większa niż po popiciu wodą; przyjęcie takrolimusu po spożyciu soku (250 ml 4 ×/d. przez $3 \mathrm{dni}$ ) powoduje o 1000\% wyższe stężenie krążącego leku. Co więcej, zastosowanie takrolimusu po przyjęciu znacznej ilości (autorzy nie określili, jakiej) dżemu/marmolady grejpfrutowej w tygodniu poprzedzającym leczenie z zastosowaniem takrolimusu powoduje wzrost stężenia tego leku o 500\% i niewydolność nerek. Wreszcie znane są doniesienia o zwiększonym ryzyku wystąpienia raka piersi w czasie leczenia hormonami płciowymi (etynyloestradiol i 17 beta-estradiol) w ramach hormonalnego leczenia zastępczego u kobiet spożywających grejpfruty w porównaniu z grupą kobiet niespożywających tego owocu, choć należy podkreślić, że nie są one jednoznaczne [27]. 
W badaniu Woźnickiej-Leśkiewicz i wsp. [19] wykazano, że pokarmy bogate w wapń, takie jak: mak, sardynki w oleju, suche nasiona soi oraz białej fasoli, natka pietruszki, orzechy laskowe i jarmuż, mogą zmniejszyć wchłanianie propranololu i atenelolu oraz skuteczność działania werapamilu, a także w przypadku spożywania ich z hydrochlorotiazydem mogą prowadzić do hiperkalcemii. Na podstawie badań stwierdzono interakcję zachodzącą między żywnością będącą źródłem witaminy D (mięso ryb, tran, wątroba, żółtko jaj, ser) a lekami z grupy antagonistów kanału wapniowego oraz między pokarmami bogatymi w witaminę $\mathrm{C}$ (czarna porzeczka, truskawka, cytryna, grejpfrut, pomarańcza, gotowane: jarmuż, brukselki, brokuł oraz papryka żółta i czerwona) a beta-adrenolitykami [19, 31].

W badaniu Saran-Jagodzińskiej i Wytlib [32] z 2018 roku stwierdzono potencjalne zagrożenie występowania interakcji między lekami z grupy inhibitorów ACE a dużymi ilościami soku pomidorowego (szklanka soku pomidorowego spożywana jednocześnie z lekiem). Natomiast Suliburska i wsp. [33] w badaniu oceny sposobu żywienia i stanu odżywienia pacjentów z pierwotnym nadciśnieniem tętniczym w aspekcie stosowanej farmakoterapii wykazali ryzyko występowania oddziaływania między papryką a lekami z grupy inhibitorów ACE. Substancja czynna zawarta w papryce kapsaicyna - wzmagała kaszel (objaw obserwowany przy stosowaniu leków z grupy inhibitorów ACE) u pacjentów spożywających paprykę wraz z enalaprilem [32, 33].

$\mathrm{Na}$ koniec warto przytoczyć doniesienia w zakresie interakcji pomiędzy witaminą $D$ a lekami obniżającymi cholesterol. Co prawda, tylko 10\% dziennego zapotrzebowania na witaminę D pochodzi z pożywienia, niemniej wobec powszechnego jej stosowania warto rozpatrzyć również tę zależność. Niedobór witaminy D może zwiększać ryzyko wystąpienia mialgii u pacjentów leczonych statynami. Zmniejszona aktywność enzymu CYP towarzysząca niedoborowi witaminy $D$ może odpowiadać za zwiększenie toksyczności statyn, z kolei wyrównanie niedoborów tej witaminy zmniejsza ryzyko wystąpienia opisywanych powikłań $w$ trakcie leczenia statynami. Co więcej, opisano także, że równoczesne stosowanie witaminy $\mathrm{D}$ i statyn może pozwolić na zmniejszenie dawki tych drugich, a w konsekwencji obniżyć ryzyko wystąpienia działań niepożądanych, w tym miopatii, w przypadku: atorwastatyny, simwastatyny, fluwastatyny i lowastatyny. W przypadku innych statyn, takich jak prawastatyna, pitawastatyna i rosuwastatyna, wpływ równocześnie stosowanej witaminy $\mathrm{D}$ może być niewielki lub żaden. Warto zwrócić uwagę na możliwe interakcje skutkujące zmniejszeniem efektywności leczenia [34].

\section{Podsumowanie}

Osoby cierpiące na CVD i regularnie przyjmujące leki kardiologiczne są narażone na występowanie interakcji między żywnością a lekami. Istnieje pilna potrzeba edukacji pacjentów w obszarze interakcji leków z żywnością. W tym celu należy utworzyć zespół terapeutyczny, składający się z: lekarza prowadzącego, lekarza specjalisty - kardiologa, psychologa, pielęgniarki oraz dietetyka, który pełniłby kompleksową opiekę nad pacjentem kardiologicznym, dobierając odpowiednią dietę do pobieranych leków w celu zapewnienia działania leczniczego i uniknięcia interakcji lek-pokarm.

\section{Konflikt interesów}

Autorzy nie zgłaszają konfliktu interesów.

\section{Abstract}

The ageing society and the growing problem of fragility syndrome necessitate the long-term use of cardiac drugs, thereby increasing the risk from drug/food interactions. The aim of this study was to present the interaction between foods and those drugs used in the clinical practice of cardiologists. The effect of vitamin $\mathrm{K}$ antagonists is intensified by food and drink such as sage, camomile, parsley, aniseed, liquorice, ginger, ginseng, cranberry juice, and grapefruit juice, among others. However, products rich in vitamin $\mathrm{K}$ inhibit the therapeutic effect of coumarin derivatives. Due to the increased risk of bleeding, antiplatelet drugs should not be combined with dietary supplements containing Ginkgo biloba which inhibits platelet activating factor. The literature indicates the occurrence of a similar risk when combining antiplatelet drugs with garlic-containing supplements. Numerous scientific studies have looked at the impact of food on the absorption of antihypertensive drugs. The best known of these is grapefruit/grapefruit juice. It was recently found that grapefruit acts by interfering in the activity of cytochrome P450 3A4 (CYP3A4) enzyme. People who regularly take cardiac drugs are exposed to food/drug interactions, and should be aware of the possible complications. There is an urgent need to educate patients in the area of food/drug interactions. Therefore, a therapeutic team should be created consisting of a general practitioner, a cardiologist, a psychologist, a nurse and a dietician.

Key words: interactions, cardiovascular drugs, dietary components

Folia Cardiologica 2019; 14, 1: 46-51 


\section{Piśmiennictwo}

1. Główny Urząd Statystyczny 2015. Zdrowie i zachowanie zdrowotne mieszkańców Polski w świetle Europejskiego Ankietowego Badania Zdrowia (EHIS). 2014: 1-12.

2. Ksiądzyna D, Szeląg A. Specyfika farmakoterapii pacjentów w podeszłym wieku. Psychoger Pol. 2013; 10(3): 115-126.

3. Swora-Cwynar E, Marcinkowska E, Olejniczak M. Interactions between food and drugs. Nursing and Public Health. 2015; 5(4): 427-439, doi: 10.17219/pzp/61697.

4. Woroń J. Błędy w leczeniu przeciwzakrzepowym, czyli 7 grzechów głównych stosowania leków przeciwzakrzepowych, przeciwpłytkowych oraz przeciwkrwotocznych w praktyce lekarskiej. Anest Ratow. 2017; 11: 211-221.

5. Di Minno A, Frigerio B, Spadarella G, et al. Old and new oral anticoagulants: food, herbal medicines and drug interactions. Blood Rev. 2017; 31(4): 193-203, doi: 10.1016/j.blre.2017.02.001, indexed in Pubmed: 28196633.

6. Woźnicka-Leśkiewicz L, Wolska-Bułach A, Tykarski A. Interakcje antykoagulantów z lekami i żywnością - wskazówki dla lekarza praktyka. Chor Serca Naczyń. 2014; 11(2): 78-90.

7. Ciborowska H, Rudnicka A. Dietetyka. Żywienie zdrowego i chorego człowieka. PZWL 2009: 149.

8. Kim KH, Choi WS, Lee JH, et al. Relationship between dietary vitamin $\mathrm{K}$ intake and the stability of anticoagulation effect in patients taking long-term warfarin. Thromb Haemost. 2010; 104(4): 755-759, doi: 10.1160/TH10-04-0257, indexed in Pubmed: 20664899.

9. Saito $\mathrm{R}$, Takeda $\mathrm{K}$, Yamamoto $\mathrm{K}$, et al. Nutri-pharmacogenomics of warfarin anticoagulation therapy: VKORC1 genotype-dependent influence of dietary vitamin $\mathrm{K}$ intake. J Thromb Thrombolysis. 2014; 38(1): 105-114, doi: 10.1007/s11239-013-0978-9, indexed in Pubmed: 23928870.

10. Rosłonkiwicz K, Sjebert J. Wpływ czynników środowiskowych na działanie antykoagulantów doustnych. Forum Med Rodz. 2013; 7(4): 208-214.

11. Kasprzak J, Dąbrowski R, Barylski M, et al. Doustne antykoagulanty nowej generacji - aspekty praktyczne. Stanowisko Sekcji Farmakoterapii Sercowo-Naczyniowej Polskiego Towarzystwa Kardiologicznego. Folia Cardiol. 2016; 11(5): 377-393, doi: 10.5603/fc.2016.0064.

12. Mądra-Gackowska K, Gackowski M, et al. Siedlecka-Główczewska Możliwości terapeutyczne wykorzystania kwasu acetylosalicylowego w populacji pacjentów geriatrycznych. Gereontol Pol. 2017; 25: 212-215.

13. Bąk-Romaniszyn L, Czkwianianc E, Cywińska-Bernas A. Choroby społeczne i cywilizacyjne - wybrane zagadnienia. Uniwersytet Medyczny, Łódź 2013: 65.

14. Kowalczyk A, Błaszczyk F, Orłowska A, et al. Ryzyko wystąpienia interakcji pomiędzy lekami a preparatami pochodzenia roślinnego wśród pacjentów objętych opieką paliatywną i hospicyjną. Med Paliat. 2014; 6(3): 140-144.

15. Lim JW, Chee SX, Wong WJ, et al. Traditional Chinese medicine: herb-drug interactions with aspirin. Singapore Med J. 2018; 59(5): 230239, doi: 10.11622/smedj.2018051, indexed in Pubmed: 29796686.

16. Gajewski P, Tomaniak M, Filipiak K. Paraoksonaza 1 - co o niej obecnie wiadomo? Folia Cardiol. 2015; 10(3): 183-189.

17. Tykarski A, Widecka K, Narkiewicz K, et al. Leki złożone w terapii nadciśnienia tętniczego w Polsce. Stanowisko Ekspertów Polskiego Towarzystwa Nadciśnienia Tętniczego oraz Sekcji Farmakoterapii
Sercowo-Naczyniowej Polskiego Towarzystwa Kardiologicznego. Arterial Hypertens. 2017; 21(3): 105-115, doi: 10.5603/ah.2017.0014.

18. Mroczek A, Pawlicki M, Pawlicka M. Nadciśnienie tętnicze - epidemiologia i etiologia. In: Bednarski J. ed. Nauki Przyrodnicze i Medyczne: Żywienie, sport oraz zdrowie. Instytut Promocji Kultury i Nauki, Lublin 2018: 143-151.

19. Woźnicka-Leśkiewicz L, Wolska-Bułach A, Posadzy-Małaczyńska A. Interakcje między lekami hipotensyjnymi i żywnością. Arterial Hypertens. 2011; 15(3): 201-209.

20. Ramalingam K, Rajagopal SS, Kandasamy K, et al. A prospective study on potential drug interactions among hospitalized patients in the cardiology departments in tertiary care hospitals. Indian J Ap Res. 2018; 8(5): 65-68.

21. Currie GM. Pharmacology, Part 2: Introduction to Pharmacokinetics. J Nucl Med Technol. 2018; 46(3): 221-230, doi: 10.2967/ jnmt.117.199638, indexed in Pubmed: 29724803.

22. Fugh-Berman A, Ernst E, Fugh-Berman A. Herb-drug interactions. Lancet. 2000; 355(9198): 134-138, doi: 10.1016/S01406736(99)06457-0, indexed in Pubmed: 10675182.

23. Matławska I. Farmakognozja. UM Poznań, Poznań 2008: 256-274.

24. Langer D, Stryczyński Ł, Szturo A, et al. Nadciśnienie tętnicze indukowane przez lukrecję. Nadciśnienie Tętnicze. 2014; 18(3): 121-126.

25. Pirmohamed M. Drug-grapefruit juice interactions: two mechanisms are clear but individual responses vary. BMJ. 2013; 346: f1, doi: 10.1136/bmj.f1, indexed in Pubmed: 23297175.

26. Bailey DG, Dresser G, Arnold JM. Grapefruit-medication interactions: forbidden fruit or avoidable consequences? CMAJ. 2013; 185(4): 309316, doi: 10.1503/cmaj.120951, indexed in Pubmed: 23184849.

27. Spencer EA, Key TJ, Appleby PN, et al. Prospective study of the association between grapefruit intake and risk of breast cancer in the European Prospective Investigation into Cancer and Nutrition (EPIC). Cancer Causes Control. 2009; 20(6): 803-809, doi: 10.1007/ s10552-009-9310-6, indexed in Pubmed: 19224379.

28. Holmberg MT, Tornio A, Neuvonen M, et al. Grapefruit juice inhibits the metabolic activation of clopidogrel. Clin Pharmacol Ther. 2014; 95(3): 307-313, doi: 10.1038/clpt.2013.192, indexed in Pubmed: 24067745.

29. Bartmańska M, Adamczak M, Więcek A. Selected food products that may cause increase of blood pressure. Nadciśnienie Tętnicze. 2013; 17(5): 384-392.

30. Zachwieja Z. Interakcje leków z pożywieniem. Medpharm, Wrocław 2008: 195-247.

31. Milešević J, Samaniego L, Kiely M, et al. Specialized food composition dataset for vitamin $D$ content in foods based on European standards: application to dietary intake assessment. Food Chem. 2018; 240: 544-549, doi: 10.1016/j.foodchem.2017.07.135, indexed in Pubmed: 28946309.

32. Saran-Jagodzińska A, Wytlib A. Ocena wiedzy osób starszych z powiatu konińskiego na temat interakcji leków z żywnością. Geriatr. 2018; 12: $19-28$.

33. Suliburska J, Bogdański P, et al. Chiniewicz Ocena sposobu żywienia i stanu odżywienia pacjentów z pierwotnym nadciśnieniem tętniczym w aspekcie stosowanej farmakoterapii. Farm Współ. 2010; 3: 5-10.

34. Bhattacharyya S, Bhattacharyya K, Maitra A. Possible mechanisms of interaction between statins and vitamin D. QJM. 2012; 105(5): 487 491, doi: 10.1093/qjmed/hcs001, indexed in Pubmed: 22323613. 